\title{
Ethnobotanical Survey of Medicinal Plants Used by Traditional Healers to Treat Diabetes in the Taza Region of Morocco
}

\author{
Hanae Naceiri Mrabti, ${ }^{1}$ Abdelhakim Bouyahya $\left(\mathbb{D},{ }^{2}\right.$ Nidal Naceiri Mrabti, ${ }^{3}$ Nidal Jaradat $\left(\mathbb{D},{ }^{4}\right.$ \\ Latifa Doudach, ${ }^{5}$ and My El Abbes Faouzi $\mathbb{D}^{1}$ \\ ${ }^{1}$ Laboratory of Pharmacology and Toxicology, Bio Pharmaceutical and Toxicological Analysis Research Team, \\ Faculty of Medicine and Pharmacy, Mohammed V University in Rabat, BP 6203, Rabat, Morocco \\ ${ }^{2}$ Laboratory of Human Pathologies Biology, Department of Biology, \\ Faculty of Sciences, and Genomic Center of Human Pathologies, Mohammed V University in Rabat, Rabat, Morocco \\ ${ }^{3}$ Computer Chemistry and Modeling Team, Laboratory of Materials, Modeling and Environmental Engineering, LIMME, \\ Faculty of Sciences Dhar El Mehraz, Sidi Mohammed Ben Abdellah University, USMBA, BP.1796, 30000, Atlas, Fez, Morocco \\ ${ }^{4}$ Department of Pharmacy, Faculty of Medicine and Health Sciences, An-Najah National University, P.O. Box 7, Nablus, \\ State of Palestine \\ ${ }^{5}$ Department of Biomedical Engineering Medical, National School of Arts and Crafts Rabat (ENSAM), Mohammed V University, \\ BP 6203, Rabat, Morocco
}

Correspondence should be addressed to Hanae Naceiri Mrabti; naceiri.mrabti.hanae@gmail.com and Abdelhakim Bouyahya; boyahyaa-90@hotmail.fr

Received 5 February 2021; Revised 4 April 2021; Accepted 13 April 2021; Published 26 April 2021

Academic Editor: Ahmed Mediani

Copyright ( $\odot 2021$ Hanae Naceiri Mrabti et al. This is an open access article distributed under the Creative Commons Attribution License, which permits unrestricted use, distribution, and reproduction in any medium, provided the original work is properly cited.

\begin{abstract}
Type 2 diabetes is one of the noncommunicable diseases that is becoming a pandemic in Africa. In Morocco, traditional healers have started to use herbal medicines for the treatment of diabetes either individually or in combination with food. The current study aimed to perform an ethnobiological survey of antidiabetic plants use in the Taza region of Morocco. A total of 193 traditional healers were interviewed using a semistructured questionnaire. Data collected were analyzed utilizing the use value (UV), fidelity level (FL), and relative frequency citation (RFC) indices. Forty-six plant species belonging to 28 families were recorded for the treatment of diabetes in the Taza region of Morocco. The most frequently cited plant species are Salvia officinalis, Marrubium vulgare, and Ajuga iva. Lamiaceae, Asteraceae, and Fabaceae were the most reported families. Leaves are the most used part of plants to prepare drugs, the decoction is the preferred mode of preparation, and remedies are often administered orally. Interestingly, Cytisus battandieri, Urginea maritima, Plantago ovata, and Ziziphus jujuba were reported as new medicinal plants used to treat diabetes in the Taza region of Morocco. People in the Taza region still rely on indigenous plants for their basic healthcare needs. Further research should be carried out to validate the antidiabetic effect of the newly reported plant species. This validation can be investigated by the determination of bioactive compounds and evaluation of their in vitro and in vivo antidiabetic effects.
\end{abstract}

\section{Introduction}

Herbal medicine is an alternative or a parallel treatment in many acute and chronic diseases. It is generating renewed interest in many countries around the world, particularly in North Africa. Indeed, a large number of plants are used in traditional medicine in Morocco, including some for the treatment of diabetes [1]. Despite the presence of antidiabetic drugs known on the pharmaceutical market, herbal remedies are importantly used to treat this disease [2]. Indeed, good knowledge and authentication of medicinal species in particularly by their vernacular names can avoid the problems of their side effects and toxicities [3]. However, for millennia, herbal medicines have been a valuable source 
of therapeutic agents, and many of today's drugs are inspired from natural herbal plants or their derivatives [4].

Scientific research on traditional herbal remedies for diabetes can provide valuable leads for the development of alternative medicines and strategies $[5,6]$. Despite numerous studies carried out in Morocco to bring up rational science about the use of plants by the local populations $[1,7-9]$, there is still a need to pursue investigation in order to have a comprehensive database on medicinal plants used for diabetes management. The available literature showed several Moroccan medicinal species with antidiabetic properties [6]. Although some of these plants have a great reputation in traditional medicine, many remain to be scientifically demonstrated [10].

In Morocco, as in developing countries, the use of traditional medicine is widespread, and several herbal remedies used individually or in combination with conventional medicines are recommended to treat diabetes [8]. Indeed, recently an ethnobotanical survey was carried out in the Beni Mellal region of Morocco [11] to collect the data about the traditional herbal medicine used for diabetes treatment in this region. So far, no scientific investigation has been carried out in the Taza region. Therefore, the current study aims to perform an ethnopharmacological survey on traditional knowledge of medicinal plants used to treat diabetes in the Taza region.

\section{Materials and Methods}

2.1. Study Area. This study was conducted in the province of Taza, situated in the northeast of Morocco. It is bounded by the Rif in the North, the Middle Atlas in the South, the Rharb plain in the West, and the Guercif plain in the East (Figure 1); it constitutes the northern termination of the Middle Atlas and extends over a length of $50 \mathrm{~km}$ and a width of $15 \mathrm{~km}$. The altitudes are between 500 and $1980 \mathrm{~m}$. The temperature varies between 3.2 and $44.5^{\circ} \mathrm{C}$. Although annual rainfall in this region has ranged between 84 and $120 \mathrm{~mm}$ over the last 8 years [12], the climate is subtropical to tropical, very dry on the coast, and wetter at altitude.

2.2. Ethnobotanical Survey. An ethnobotanical survey was conducted from March 2019 to February 2020, and before starting the collection of ethnobotanical data, a brief explanation to the informants on the objectives of the study and the importance of the information they would provide was provided in order to obtain their consent to participate in the study. A total of 193 healers were interviewed for this purpose. The data were collected through semistructured interviews using Moroccan language (Darija). These interviews were designed to record information about the plants used to treat diabetes mellitus and their local names, the used parts of the plant, the methods of preparation, the administration of drugs, and the demographic characteristics of the study participants.

2.3. Preservation of Plant Specimens. The standard method was followed with a record to collect the plant materials, drying, mounting, preparation, and preservation in special glass frames; they were later identified by Pr. Latifa Doudach. These samples of plant material were given herbarium specimen codes, and the voucher plant samples were kept in the Herbarium of the Botany Department of the Scientific Institute of Rabat, Morocco. The complete floristic list was established after the identification and verification of the samples; the identification process included the Traditional Moroccan Pharmacopeia [13], Practical Flora of Morocco [14], Moroccan Medicinal and Aromatic Plants [15], and Vascular Flora of Morocco [14] as references. The taxonomy was confirmed based on data available on the International Plant Names Index website: http://www.ipni.org/.

2.4. Data Analysis. Medicinal plants inventoried in this study were organized in alphabetical order by family. The data reported concerned family, scientific name, local name, part used the utilized preparations, main therapeutic use, and identification code. The obtained results were analyzed using specific quantitative parameters.

2.4.1. Use Value (UV). The use value (UV) demonstrates the relative importance of plants known locally in traditional medicine [16]. Use value (UV) was calculated using the following formula:

$$
\mathrm{UV}=\frac{\sum U}{n},
$$

where UV is the use value of species, $U$ is the number of respondents who mentioned the use of the species, and $n$ is the total number of respondents interviewed for a given species (herbalists and local population). The highest use recorded in inquiry reports for a given plant gives a rise to the highest UV value.

2.4.2. Fidelity Level (FL). Fidelity level (FL) indicates the percentage of informants claiming the use of a certain plant species for the same major purpose [17]. The fidelity level is calculated by the following formula:

$$
\mathrm{FL}(\%)=\frac{N_{p}}{N} \times 100,
$$

where $N_{p}$ is the number of informants who independently indicated the use of a species for the same major ailment and $N$ is the total number of informants who mentioned the plant for any major ailment.

2.4.3. Relative Frequency Citation (RFC). The collected ethnomedicinal information was quantitatively analyzed using an index of relative frequency citation (RFC) $(0<\mathrm{RFC}<1)$ :

$$
\mathrm{RFC}=\frac{\mathrm{FC}}{N} .
$$

This index shows the local importance of each species, and it is given by the frequency of citation (FC, the number of informants mentioning the use of the species) divided by 

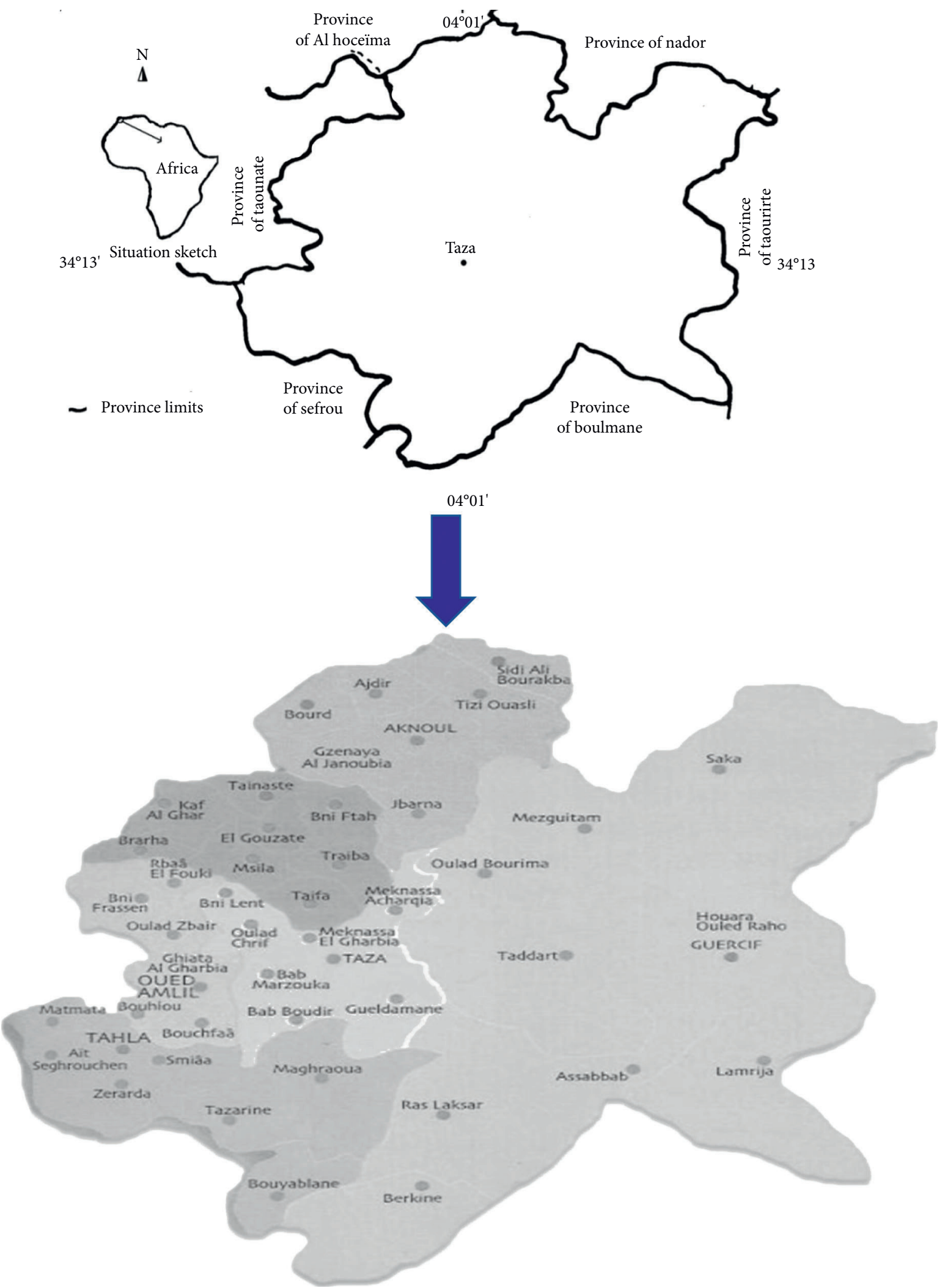

FIGURE 1: Map of the study area. 
the total number of informants participating in the survey $(N)$, without considering the use categories [16].

\section{Results and Discussion}

3.1. Demographic Features. This study enrolled 193 informants, including traditional healers, herbalists, and knowledgeable villagers represented by 169 women $(87.56 \%)$ and 24 men (12.44\%), and they were interviewed (Table 1). The results showed that women were more involved in the use of medicinal plants than men, and this could be explained by the activities of women at home. Indeed, they were responsible for drying, storing, and the preparation of the herbal remedy for maintaining the healthcare of their family. Their average age was 59.5 years with a minimum of 32 years and a maximum of 87 years. The age group [18-38] was the most represented with $46.11 \%$. The majority of the respondents belong to the rural area (92\%); and $84.45 \%$ are illiterate, $12.95 \%$ primary education, $2.07 \%$ secondary education, and $0.51 \%$ university education. Regarding the origin of their knowledge, the majority of them $(96.89 \%)$ who participated in this survey acquired the traditional medical knowledge of their family members, mainly grandparents and parents, and this knowledge has not been documented.

3.2. Medicinal Plants and Floristic Analysis. This ethnobotanical survey revealed the presence of 46 plant species, belonging to 28 families used for the treatment of diabetes by participants from the Taza region, and these species were reported along with their medicinal uses and their methods of use (Table 2). The most common medicinal plant family is Lamiaceae (6 species), Asteraceae and Fabaceae (5 species each), and Apiaceae and Myrtaceae (3 species each), respectively, whereas the other families were represented with a variable number of fewer than 2 species.

3.3. Ethnobotanical Indices. In this study, the analysis of data collected in the field allowed us to determine forty-six (46) most commonly cited plants known to most medical informants about the treatment of diabetes disease (Table 2). The obtained data were analyzed and ordered based on the value of use (UV), level of accuracy (FL), and relative citation frequency (RFC). The values of the collected plant species ranged from 0.01 to 1.63 for UV; 8.33 to $95.34 \%$ for FL, and 0.01 to 1 for RFC, respectively. Among 46 inventoried species, ten plants species identified had high FL values (FL of $>50 \%$ ), which are Salvia officinalis, Marrubium vulgare, Trigonella foenum-graecum, Olea europaea, Artemisia herbaalba, Ajuga iva, Arbutus unedo, Euphorbia resinifera, Taraxacum officinale, and Ceratonia siliqua. Likewise, while Salvia officinalis (1.00) has the highest value of RFC followed by Marrubium vulgare (0.97) and Ajuga iva (0.94), respectively. These positions correspond to the fact that these plants were reported by the highest number of informants and RFC directly depends on the number of informants mentioning the use of this plant (FC). As shown in Table 2, S. officinalis has the highest use value (1.63) followed by M. vulgare (1.53) and A. iva (1.46).
TABle 1: Sociodemographic characteristics and experience of herbalists.

\begin{tabular}{lcc}
\hline Characteristics & $\begin{array}{c}\text { Number of informants } \\
(n)\end{array}$ & Frequency (\%) \\
\hline Ages (years) & & \\
$30-50$ & 56 & 29.01 \\
$50-70$ & 89 & 46.11 \\
$70-90$ & 48 & 24.87 \\
Total & $\mathbf{1 9 3}$ & $\mathbf{1 0 0}$ \\
\hline Gender & & \\
Male & 24 & 12.44 \\
Female & 169 & 87.56 \\
Total & $\mathbf{1 9 3}$ & $\mathbf{1 0 0}$ \\
\hline Education & & \\
Illiterate & 163 & 84.45 \\
Primary & 25 & 12.95 \\
Secondary & 4 & 2.07 \\
University & 1 & 0.51 \\
Total & $\mathbf{1 9 3}$ & $\mathbf{1 0 0}$ \\
\hline Origin of knowledge & & \\
Family heritage & 187 & 96.89 \\
Traditional & 6 & 3.11 \\
initiation & $\mathbf{1 9 3}$ & $\mathbf{1 0 0}$ \\
Total & & \\
\hline
\end{tabular}

3.4. Comparative Analysis with the Ethnobotanical Literature. Four medicinal plants have been mentioned for the first time to treat diabetes. Indeed, the literature reviewed showed that these plants have not been reported by other Moroccan studies. These species include Cytisus battandieri, Urginea maritima, Plantago ovata, and Ziziphus jujuba (Table 2).

3.5. Plant Parts Used, Mode of Preparation, and Administration. The data showed that the leaves were the most used part (44\%) of the medicinal plants followed by seeds $(22 \%)$, flowers and fruits (10\% each), stems (8\%), and roots (5\%) (Figure 2).

The decoction was the primary mode of preparation of herbal medicines accounting for 55\% followed by powder (19\%), infusion (15\%), raw form (5\%), maceration (5\%), and inhalation (2\%) (Figure 3).

3.6. Antidiabetic Effects of Medicinal Plants Cited in This Survey. In vitro and in vivo antidiabetic effects of some of the cited plants in this survey were investigated. Indeed, four medicinal plants (A. iva, Arbutus unedo, Calendula arvensis, and Ziziphus lotus) were tested in vitro. Twelve plants (A. iva, Calamintha officinalis, Carum carvi, Ammi visnaga, Lepidium sativum, Chamaerops humilis, Capparis spinosa, Arbutus unedo, Eucalyptus globulus, Nigella sativa, and Urtica dioica) were tested in vivo (Table 3 ).

\section{Discussion}

This study reports the medicinal plants used in the Taza region to treat diabetes. The demographic features showed that women were often at home during survey hours. Some previous studies have also shown this trend $[7,8,11]$. 


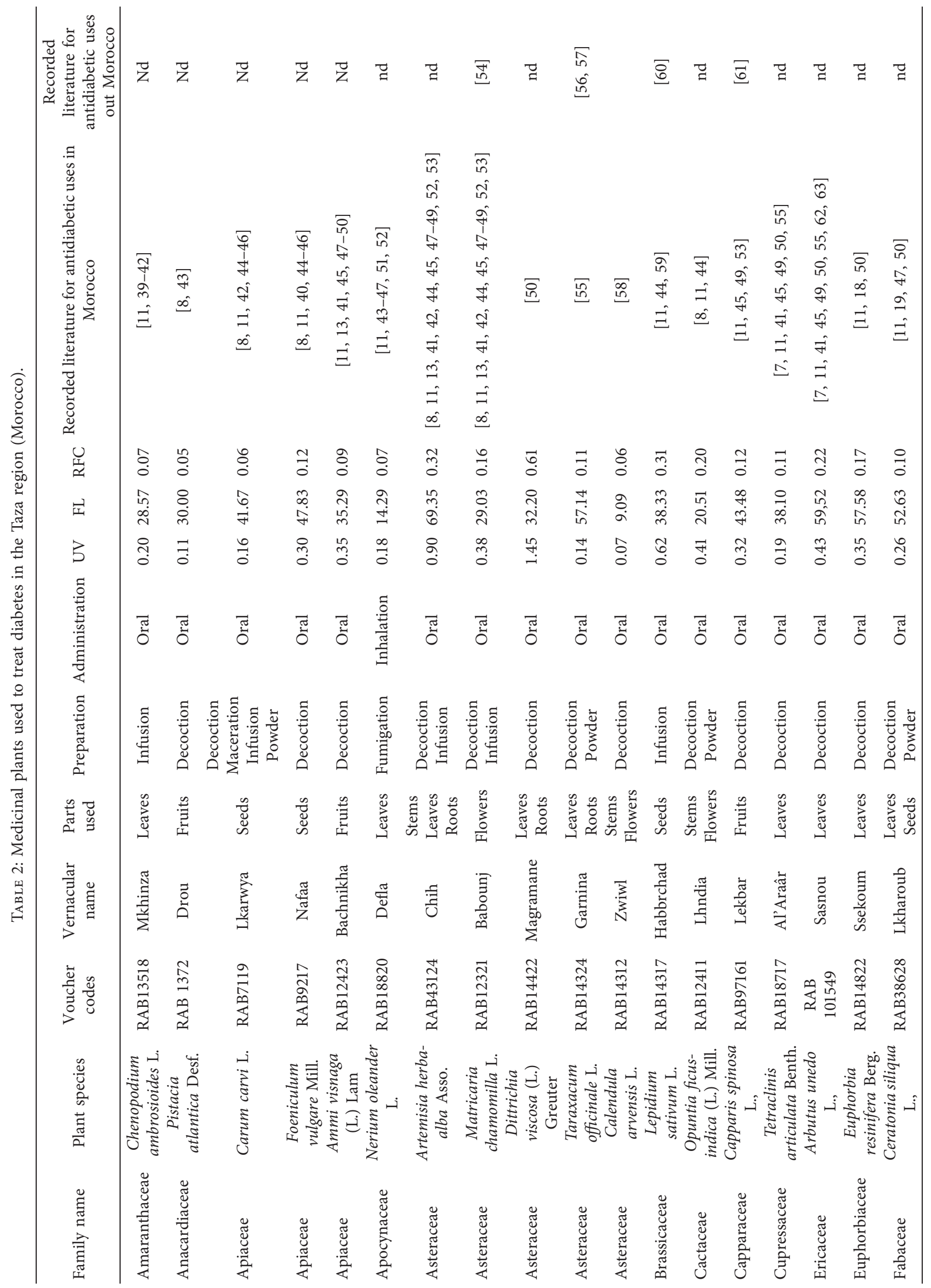




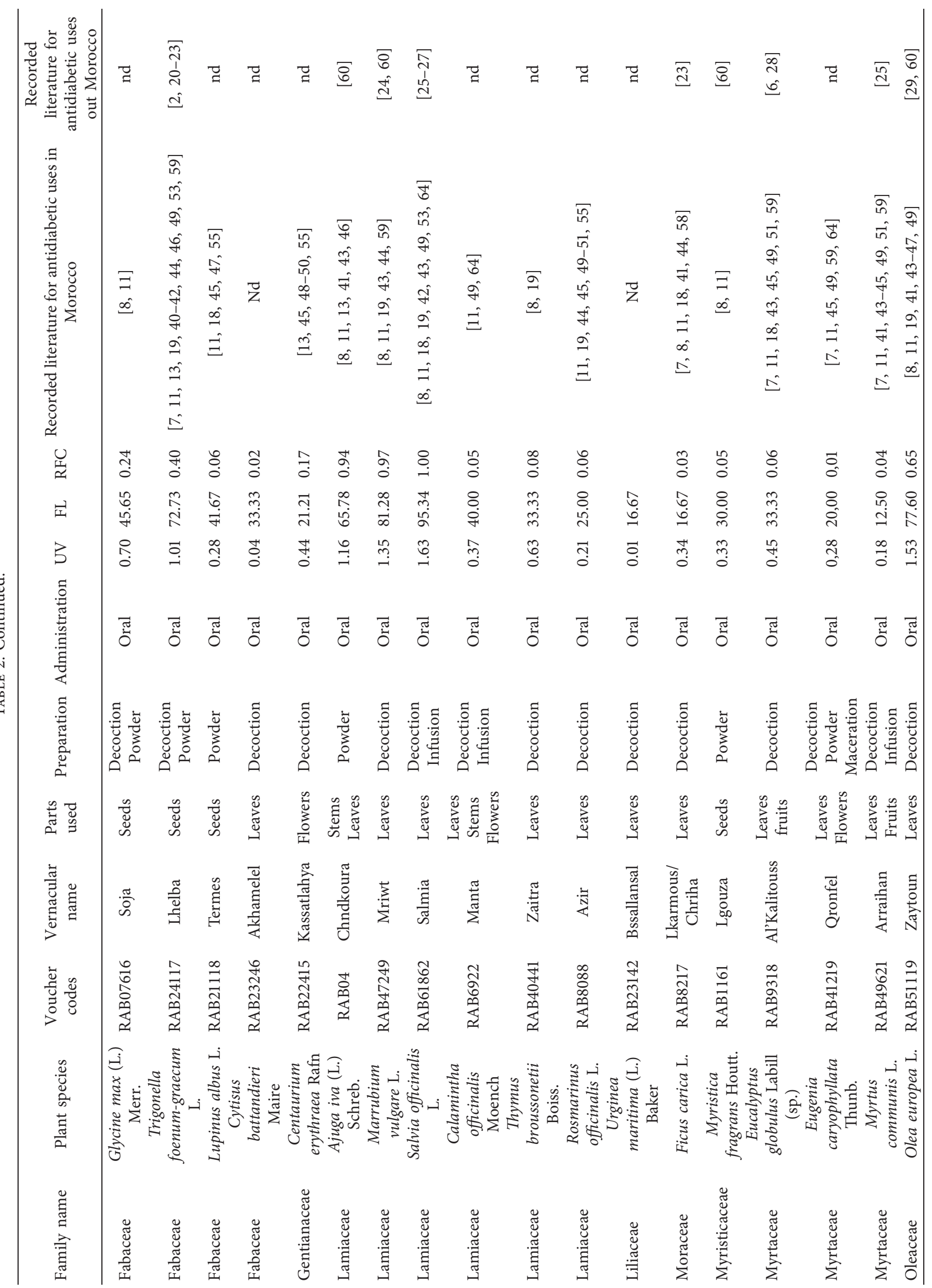




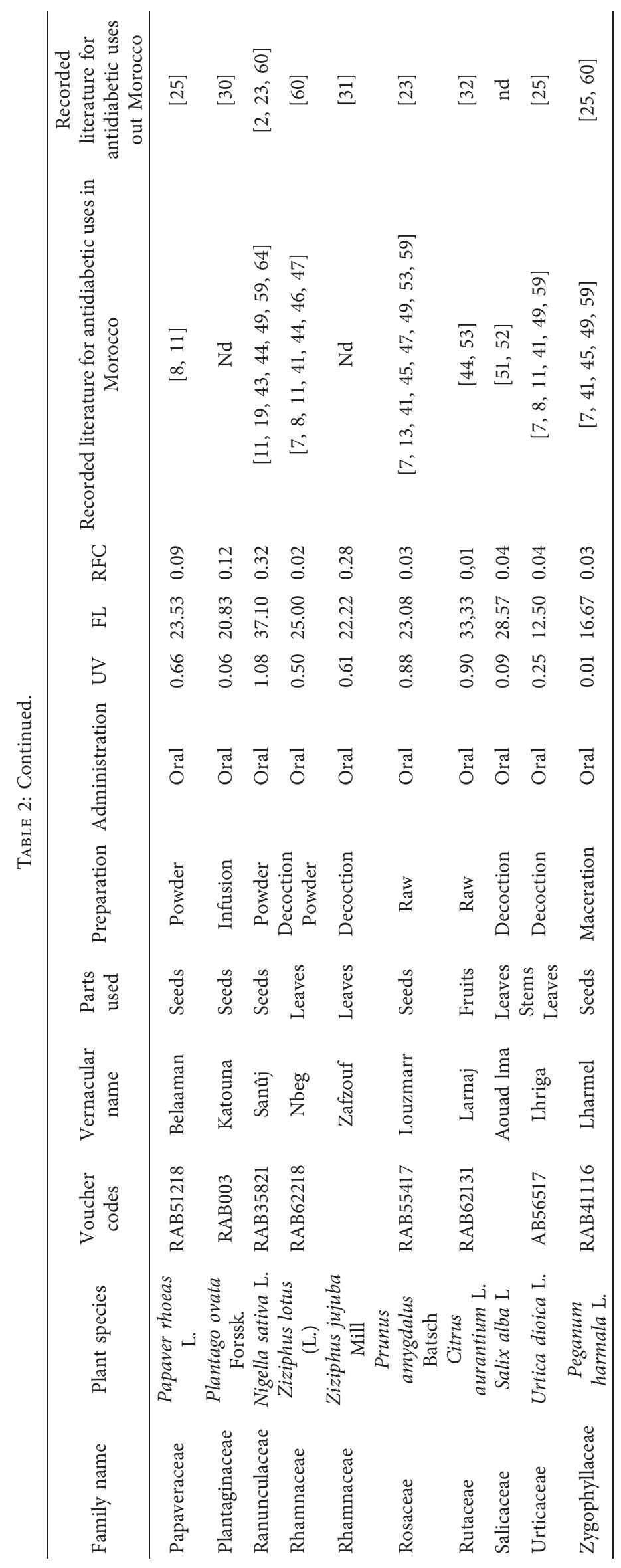




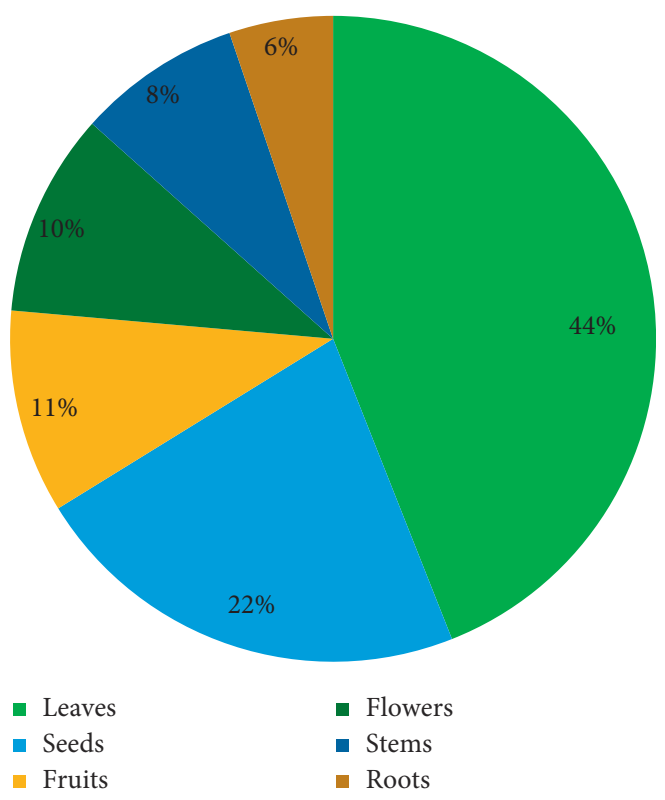

Figure 2: Medicinal use of medicinal plants of the Taza area against diabetes according to plant parts used.

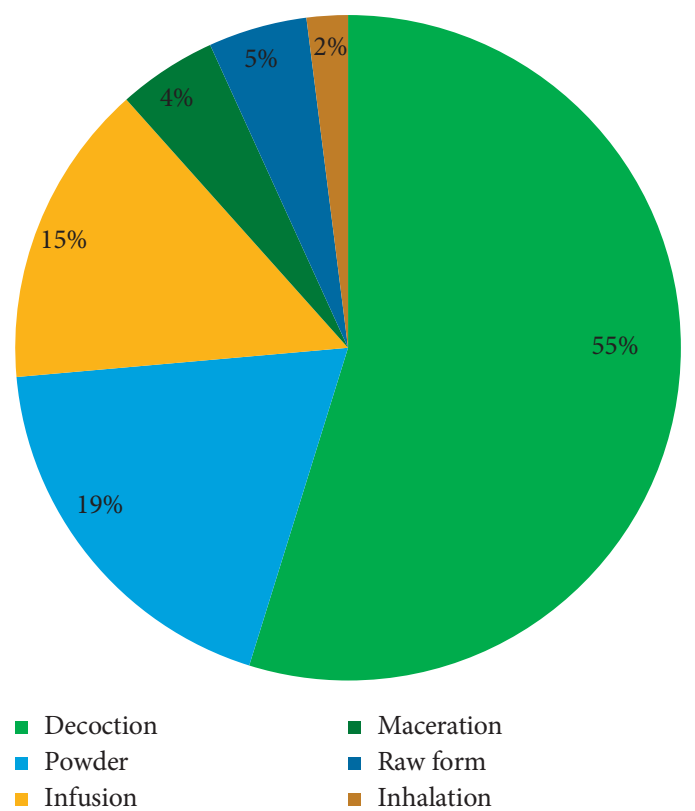

Figure 3: Medicinal use of medicinal plants of the Taza area against diabetes according to the preparation methods.

Moreover, the interviews showed that the elderly were particularly competent and had better knowledge of plants than the young; similar results have been observed in other studies where indigenous knowledge on the use of medicinal plants is still strong with the elderly [81-83]. On the other hand, results revealed that the majority of the respondents belong to rural areas and are illiterate. These results are corroborated by other studies, which have shown that illiterate people have more expertise in the uses of traditional medicine [5].

Medicinal plants diversity showed a floristic diversity. Indeed, the findings were in agreement with previous studies, where these families were the most represented in diabetes mellitus treatment in Morocco [8, 44, 47, 64], Turkey [84], and Togo [85]. The reasons for the high degree of ethnomedicinal plants of families Lamiaceae, Asteraceae, Fabaceae, Apiaceae, and Myrtaceae in the region is their wide occurrence with several traditional uses known by the local informants [8].

The survey revealed that $S$. officinalis, M. vulgare, and A. iva are the most used in traditional medicine to treat diabetes in this region. Literature reports showed that several of these plants have been reported in other ethnomedical surveys for the treatment of diabetes 
TABLE 3: In vitro and in vivo antidiabetic cited medicinal plants in this survey.

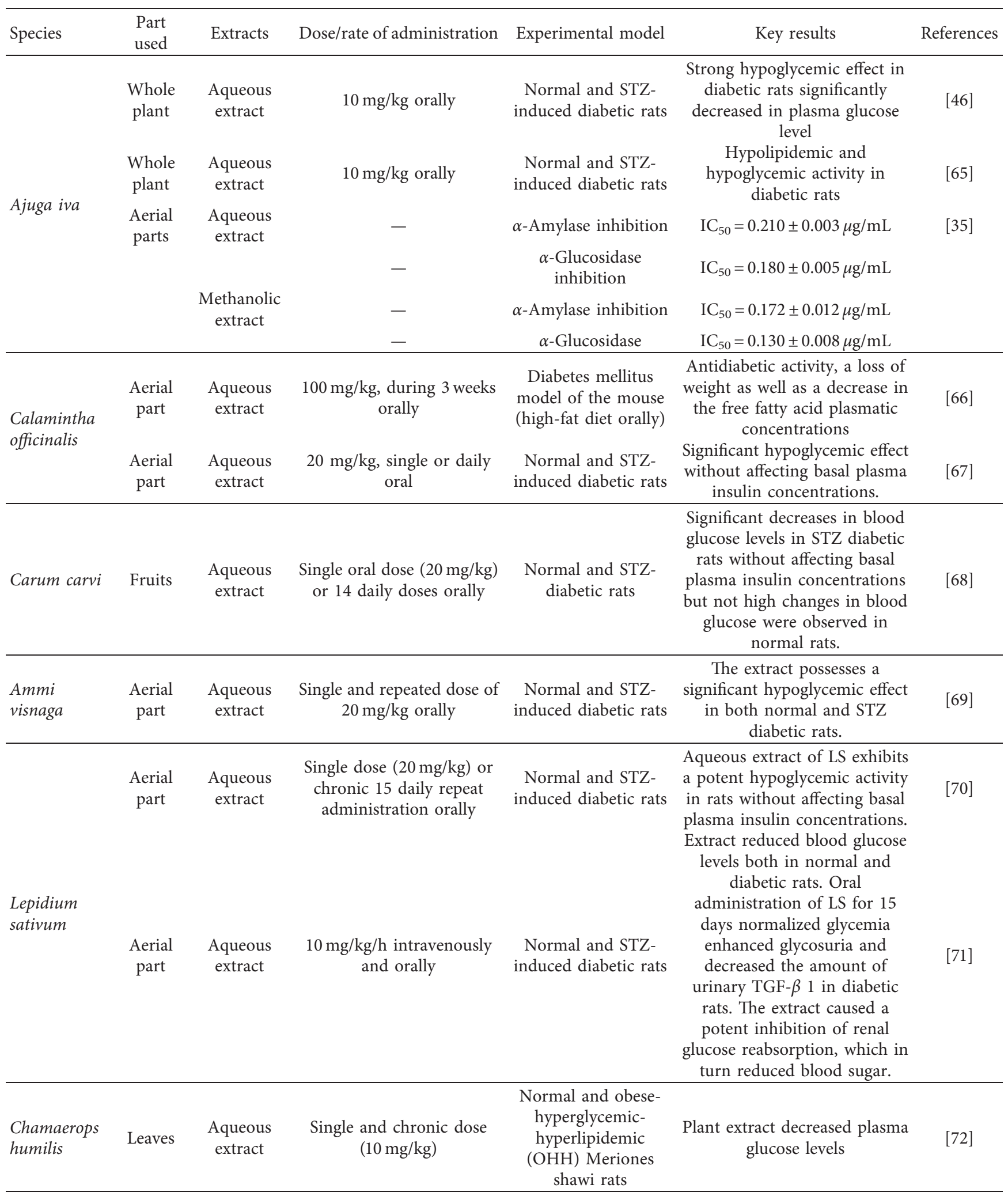


TABle 3: Continued.

\begin{tabular}{|c|c|c|c|c|c|c|}
\hline Species & $\begin{array}{l}\text { Part } \\
\text { used }\end{array}$ & Extracts & Dose/rate of administration & Experimental model & Key results & References \\
\hline \multirow{3}{*}{$\begin{array}{l}\text { Capparis } \\
\text { spinosa }\end{array}$} & Fruits & $\begin{array}{l}\text { Aqueous } \\
\text { extract }\end{array}$ & $20 \mathrm{mg} / \mathrm{kg}$ orally & $\begin{array}{l}\text { Normal and STZ- } \\
\text { induced diabetic rats) }\end{array}$ & $\begin{array}{l}\text { Significant antihyperglycemic } \\
\text { activity in STZ rats without } \\
\text { affecting basal plasma insulin }\end{array}$ & {$[1]$} \\
\hline & & & & & concentrations & \\
\hline & $\begin{array}{c}\text { Aerial } \\
\text { part }\end{array}$ & $\begin{array}{l}\text { Aqueous } \\
\text { extract }\end{array}$ & $\begin{array}{c}100 \mathrm{mg} / \mathrm{kg} \text {, during } 3 \text { weeks } \\
\text { orally }\end{array}$ & $\begin{array}{l}\text { Diabetes mellitus } \\
\text { model of the mouse } \\
\text { (high-fat diet orally) }\end{array}$ & $\begin{array}{c}\text { Antidiabetic activity, a loss of } \\
\text { weight as well as a decrease in } \\
\text { the free fatty acid plasmatic } \\
\text { concentrations }\end{array}$ & {$[73]$} \\
\hline \multirow[t]{3}{*}{$\begin{array}{l}\text { Arbutus } \\
\text { unedo }\end{array}$} & Roots & $\begin{array}{l}\text { Aqueous } \\
\text { extract }\end{array}$ & $\begin{array}{l}400 \mathrm{mg} / \mathrm{L} \text { in the chronic } \\
\text { treatment of } \\
\text { streptozotocin-induced } \\
\text { diabetic rats } \\
\text { (intraperitoneally) } 150 \mathrm{mg} / \\
\text { kg in oral glucose tolerance } \\
\text { test (orally) }\end{array}$ & $\begin{array}{l}\text { Oral glucose tolerance } \\
\text { test normal and STZ- } \\
\text { induced diabetic rats }\end{array}$ & $\begin{array}{c}\text { Decreasing in plasma glucose } \\
\text { levels at } 31.6 \% .\end{array}$ & {$[62,63]$} \\
\hline & Roots & $\begin{array}{l}\text { Aqueous } \\
\text { extract }\end{array}$ & & $\alpha$-Amylase inhibition & $\mathrm{IC}_{50}=730.15 \pm 0.25 \mu \mathrm{g} / \mathrm{mL}$ & {$[63]$} \\
\hline & & & & $\begin{array}{c}\alpha \text {-Glucosidase } \\
\text { inhibition }\end{array}$ & $\mathrm{IC}_{50}=94.81 \pm 5.99 \mu \mathrm{g} / \mathrm{mL}$ & \\
\hline $\begin{array}{l}\text { Eucalyptus } \\
\text { globulus }\end{array}$ & Leaves & $\begin{array}{l}\text { Aqueous } \\
\text { extract }\end{array}$ & $\begin{array}{l}150 \text { and } 300 \mathrm{mg} / \mathrm{kg} \text { body } \\
\text { weight intraperitoneally }\end{array}$ & $\begin{array}{l}\text { Single and repeated } \\
\text { oral STZ-induced } \\
\text { diabetic rats }\end{array}$ & $\begin{array}{l}\text { Exhibited a significant, dose- } \\
\text { dependent hypoglycemic effect } \\
\text { in streptozotocin-induced } \\
\text { diabetic rats. The extract } \\
\text { significantly increased the basal } \\
\text { plasma insulin concentrations }\end{array}$ & {$[74]$} \\
\hline \multirow{3}{*}{ Nigella sativa } & Seeds & $\begin{array}{l}\text { Aqueous } \\
\text { extract }\end{array}$ & $2 \mathrm{~g} / \mathrm{kg} /$ day orally & $\begin{array}{l}\text { Short-circuit current } \\
\text { technique oral glucose } \\
\text { tolerance test }\end{array}$ & $\begin{array}{l}\text { Inhibited the electrogenic } \\
\text { intestinal absorption of glucose } \\
\text { in vitro chronic treatment } \\
\text { improved glucose tolerance in } \\
\text { rats also reduced body weight } \\
\text { without any toxic effect. }\end{array}$ & {$[75]$} \\
\hline & Seeds & $\begin{array}{l}\text { Petroleum } \\
\text { ether extract }\end{array}$ & $\begin{array}{l}2 \mathrm{~g} / \mathrm{kg} / \text { day during four- } \\
\text { week intragastric gavage }\end{array}$ & $\begin{array}{l}\text { STZ-induced diabetic } \\
\text { rats }\end{array}$ & $\begin{array}{l}\text { The petroleum ether extract } \\
\text { exerts an insulin-sensitizing } \\
\text { action by enhancing the activity } \\
\text { of the two major intracellular } \\
\text { signal transduction pathways of } \\
\text { the hormone's receptor. }\end{array}$ & {$[76]$} \\
\hline & Seeds & $\begin{array}{l}\text { Ethanol } \\
\text { extract }\end{array}$ & $\begin{array}{l}2 \mathrm{~g} / \mathrm{kg} / \text { day during four- } \\
\text { week intragastric gavage }\end{array}$ & $\begin{array}{c}\text { Oral glucose tolerance } \\
\text { test on Meriones } \\
\text { shawi rats }\end{array}$ & $\begin{array}{l}\text { Hypoglycemic and } \\
\text { hypolipidemic activity }\end{array}$ & {$[77]$} \\
\hline \multirow{6}{*}{$\begin{array}{l}\text { Calendula } \\
\text { arvensis }\end{array}$} & Flowers & $\begin{array}{c}\text { Aqueous } \\
\text { extract }\end{array}$ & & $\alpha$-Amylase & $1368.27 \pm 9.14 \mu \mathrm{g} / \mathrm{mL}$ & {$[78]$} \\
\hline & & & & $\begin{array}{c}\alpha \text {-glucosidase } \\
\beta \text {-Galactosidase }\end{array}$ & $\begin{array}{r}1121.10 \pm 6.42 \mu \mathrm{g} / \mathrm{mL} \\
2116.82 \pm 17.57 \mu \mathrm{g} / \mathrm{mL}\end{array}$ & \\
\hline & & $\begin{array}{c}\text { Methanol } \\
\text { extract }\end{array}$ & & $\alpha$-Amylase & $573.37 \pm 36.85 \mu \mathrm{g} / \mathrm{mL}$ & \\
\hline & & & & $\alpha$-Glucosidase & $848.83 \pm 49.93 \mu \mathrm{g} / \mathrm{mL}$ & \\
\hline & & $\begin{array}{l}\text { Hexane } \\
\text { extract }\end{array}$ & & $\beta$-Galactosidase & $1422.66 \pm 260.87 \mu \mathrm{g} / \mathrm{mL}$ & \\
\hline & & & & $\begin{array}{c}\alpha \text {-Amylase } \\
\alpha \text {-Glucosidase } \\
\beta \text {-Galactosidase }\end{array}$ & $\begin{array}{c}1955 \pm 28.13 \mu \mathrm{g} / \mathrm{mL} \\
1722.59 \pm 22.42 \mu \mathrm{g} / \mathrm{mL} \\
3156.98 \pm 58.17 \mu \mathrm{g} / \mathrm{mL}\end{array}$ & \\
\hline
\end{tabular}


TABLE 3: Continued.

\begin{tabular}{|c|c|c|c|c|c|c|}
\hline Species & $\begin{array}{l}\text { Part } \\
\text { used }\end{array}$ & Extracts & Dose/rate of administration & Experimental model & Key results & References \\
\hline \multirow{5}{*}{$\begin{array}{l}\text { Ziziphus } \\
\text { Lotus }\end{array}$} & Roots & Catechin & & $\begin{array}{l}\alpha \text {-Glucosidase } \\
\text { inhibition }\end{array}$ & $\mathrm{IC}_{50}=87.55 \pm 2.23 \mu \mathrm{g} / \mathrm{mL}$ & \multirow[t]{5}{*}{ [79] } \\
\hline & Fruits & $\begin{array}{l}\text { Methanolic } \\
\text { extract }\end{array}$ & & $\alpha$-Amylase inhibition & $\mathrm{IC}_{50}=31.91 \pm 1.53 \mu \mathrm{g} / \mathrm{mL}$ & \\
\hline & Leaves & $\begin{array}{c}\text { Methanolic } \\
\text { extract }\end{array}$ & & $\begin{array}{c}\alpha \text {-Glucosidase } \\
\text { inhibition }\end{array}$ & $\mathrm{IC}_{50}=27.95 \pm 2.45 \mu \mathrm{g} / \mathrm{mL}$ & \\
\hline & & & & A-Amylase inhibition & $\mathrm{IC}_{50}=20.40 \pm 1.30 \mu \mathrm{g} / \mathrm{mL}$ & \\
\hline & & & & $\begin{array}{c}\alpha \text {-Glucosidase } \\
\text { inhibition }\end{array}$ & $\mathrm{IC}_{50}=8.66 \pm 0.62 \mu \mathrm{g} / \mathrm{mL}$ & \\
\hline Urtica dioica & $\begin{array}{c}\text { Aerial } \\
\text { part }\end{array}$ & $\begin{array}{c}\text { Aqueous } \\
\text { extract }\end{array}$ & $250 \mathrm{mg} / \mathrm{kg}$ & $\begin{array}{l}\text { Oral glucose tolerance } \\
\text { test (OGTT) at dose } \\
250 \mathrm{mg} / \mathrm{kg} \text { in normal } \\
\text { and alloxan-induced } \\
\text { diabetic rats. }\end{array}$ & $\begin{array}{l}\text { Strong glucose-lowering effect } \\
\text { in normal rats and no effect in } \\
\text { alloxan-induced diabetic rats }\end{array}$ & {$[80]$} \\
\hline Urtica dioica & $\begin{array}{c}\text { Aerial } \\
\text { part }\end{array}$ & $\begin{array}{c}\text { Aqueous } \\
\text { extract }\end{array}$ & $\begin{array}{l}\text { Intraperitoneally } 400 \mathrm{mg} / \mathrm{L} \\
\text { in the chronic treatment of } \\
\text { streptozotocin-induced } \\
\text { diabetic rats. } 150 \mathrm{mg} / \mathrm{kg} \text { in } \\
\text { oral glucose tolerance test }\end{array}$ & $\begin{array}{l}\text { Oral glucose tolerance } \\
\text { test STZ-induced } \\
\text { diabetic rats }\end{array}$ & $\begin{array}{l}\text { Decrease in plasma glucose } \\
\text { levels at 31.6. Significant } \\
\text { reduction of hyperglycemia in } \\
\text { oral glucose tolerance. }\end{array}$ & {$[62]$} \\
\hline
\end{tabular}

$[7,44,45,47]$. The antidiabetic activity of certain plants has also been experimentally proven by in vivo or in vitro studies. These species include $A$. herba-alba [21, 33, 34], S. officinalis [27], O. europaea [29], A. iva [35], A. unedo [63], and $M$. vulgare [24]. Actually, certain mentioned plants open up interesting perspectives in the search for new therapeutic means, which can thus provide credible solutions by the production of low-cost and effective drugs for the treatment of diabetes.

However, the use of C. battandieri, U. maritime, P. ovate, and $Z$. jujube for managing diabetes has not been reported. International literature has shown $P$. ovate and $Z$. jujube have been used for diabetes in other countries like Iran $[30,31,36]$. The majority of these plants have been reported as medicinal plants in the treatment of other diseases. C. arvensis has been used as a disinfectant, antispasmodic, antipyretic, anti-inflammatory, antiepileptic, antimicrobial, and diuretic [37, 38]. Urginea maritima was used for the treatment of cardiac failure, chronic bronchitis, asthma, and diuretic [86]. Salix alba has been used for the treatment of various ailments due to its potent antipyretic, analgesic, and anti-inflammatory properties [87].

In addition, the part of the plant most frequently used in this study was the leaves, which corresponds to previous studies that declared that the leaves are part of the plant mainly used in the treatment of diabetes in Morocco $[8,11]$, Kenya [88], Togo [81], and Pakistan [23]. The reason for the high use of leaves can be explained by their availability and their ease of collection compared with other parts like roots, flowers, and fruits [89].

Concerning the mode of preparation, similar types of results were obtained in other studies, where decoction was the most frequent mode of preparation $[11,17,25,41]$. The most frequently used mode of herbal remedy administration is oral ingestion (98.30\%). Today, most of the medicines were given orally, which is in agreement with other studies [11, 90, 91].
A bibliometric study was carried out to identify which cited medicinal plants were already tested in vitro and in vivo for their antidiabetic effects. In vitro investigations showed that some plants were studied in vitro. Indeed, Abudunia et al. [78] have tested the in vitro antidiabetic effects of methanolic, hexane, and aqueous extracts of $C$. arvensis collected from the region of Khemisset. All tested extracts exhibited enzymatic inhibitory effects on $\alpha$-amylase, $\alpha$-glucosidase, and $\beta$-glucosidase with some variability. Indeed, methanolic extract seems to be the most effective product, in particular, against $\alpha$-amylase $\left(\mathrm{IC}_{50}=573.37 \pm\right.$ $36.85 \mu \mathrm{g} / \mathrm{mL}$ ) and $\alpha$-glucosidase $\left(\mathrm{IC}_{50}=848.83 \pm 49.93 \mu \mathrm{g} /\right.$ $\mathrm{mL})$. Saad et al. [35] showed that aqueous and methanolic extracts of Ajuga iva exhibited remarkable inhibition of $\alpha$-amylase $\left(\mathrm{IC}_{50}=0.210 \pm 0.003\right.$ and $\mathrm{IC}_{50}=0.180 \pm 0.005 \mu \mathrm{g} /$ $\mathrm{mL}$, respectively) and $\alpha$-glycosidase $\left(\mathrm{IC}_{50}=0.172 \pm 0.012\right.$ and $\mathrm{IC}_{50}=0.130 \pm 0.008 \mu \mathrm{g} / \mathrm{mL}$, respectively). The authors suggested that these effects are related to the phenolic compounds present in plant extracts. Moreover, the acute toxicity evaluation on rats showed that these extracts are not toxic [35].

The root aqueous extract of $A$. unedo has revealed significant enzyme inhibition of $\alpha$-amylase and $\alpha$-glucosidase [63]. The inhibitory effect was significantly important against $\alpha$-glucosidase $\left(\mathrm{IC}_{50}=94.81 \pm 5.99 \mathrm{mg} / \mathrm{mL}\right)$. This remarkable result led Naceiri Mrabti and collaborators to fractionate the root aqueous extract of $A$. unedo and to isolate the major compounds. The results revealed the presence of catechin as the main compound, which was isolated and tested for its inhibitory effect against $\alpha$-glucosidase [92]. Indeed, the inhibitory activity of $\alpha$-glucosidase was increased $\left(\mathrm{IC}_{50}=87.55 \pm 2.23 \mathrm{mg} / \mathrm{mL}\right)$, compared with the inhibitory activity of aqueous extract [92]. Marmouzi et al. [79] tested the methanolic extracts of leaves and fruits of $Z$. lotus (Rhamnaceae) showed significant inhibition of $\alpha$-amylase and anti- $\alpha$-glucosidase at lower concentrations 
with some differences between fruit and leaf extracts. Indeed, the leaf extract revealed higher inhibitory potency as anti$\alpha$-amylase and anti- $\alpha$-glucosidase compared with the fruit extract for which $\mathrm{IC}_{50}=20.40 \pm 1.30$ and $\mathrm{IC}_{50}=8.66 \pm$ $0.62 \mathrm{mg} / \mathrm{mL}$, respectively [79].

However, several medicinal plants cited in this survey have shown important in vivo antidiabetic effects. $U$. dioica aqueous extracts were tested using the oral glucose tolerance test and intravenous glucose tolerance test and showed that the administration of extract orally at $250 \mathrm{mg} / \mathrm{kg}$ decreased glycemia significantly, which indicates a significant inhibition of glucose absorption. Moreover, using oral glucose tolerance on normal and streptozotocin-induced diabetic rats has shown that the same extract decreases plasma glucose levels at 27.4\% [62]. Moreover, at the same concentration, another study revealed that the antidiabetic effect was also accompanied by hypolipidemic action [65]. Calamintha officinalis is another Moroccan antidiabetic medicinal plant that belongs to Lamiaceae family. On the other hand, Eddouks et al. [70] reported that the L. sativum aerial part aqueous extract (Brassicaceae) administered orally at $20 \mathrm{mg} / \mathrm{kg}$ exhibits a potent hypoglycemic effect without affecting basal plasma insulin. However, oral and intravenous administration of the same extract at $10 \mathrm{mg} / \mathrm{kg} /$ $\mathrm{h}$ in normal and STZ-induced diabetic rats caused a significant reduction of blood glucose levels in both normal and diabetic rats. Therefore, this extract normalized glycemia, enhanced glycosuria, and decreased the amount of urinary TGF- $\beta 1$ in diabetic rats. These suggest that the plant extract has a potent inhibition of renal glucose reabsorption, which reduces blood sugar [70]. Eddouks et al. [70] showed that the oral administration of $C$. humilis leaf aqueous extract at $10 \mathrm{mg} / \mathrm{kg}$ decreased plasma glucose levels in normal and obese-hyperglycemic-hyperlipidemic $(\mathrm{OHH})$ Meriones shawi rats. Moreover, another study showed that, at the dose of $20 \mathrm{mg} / \mathrm{kg}$, the hypoglycemia effect was also accompanied by the potent inhibition of renal glucose reabsorption [71]. However, in vitro study using short-circuit current technique revealed that the aqueous extract caused significant inhibition of the electrogenic intestinal absorption of glucose [75]. Bnouham et al. [80] studied the hypoglycemic effect of aerial part aqueous extracts of $U$. dioica (Urticaceae) using oral glucose tolerance test (OGTT) at a dose of $250 \mathrm{mg} / \mathrm{kg}$ in normal and alloxan-induced diabetic rats. The results showed a strong glucose-lowering effect in normal rats and no effect in alloxan-induced diabetic rats. In another work, intraperitoneal administration of aerial part aqueous extracts of this plant at a dose of $400 \mathrm{mg} / \mathrm{L}$ in the chronic treatment of streptozotocin-induced diabetic rats and $150 \mathrm{mg} / \mathrm{kg}$ in the oral glucose tolerance test caused a significant reduction of glycemia in oral glucose tolerance and plasma glucose levels [62].

The study highlighted results about antidiabetic medicinal plants as a source of antidiabetic drugs for further investigations, in particular for medicinal plants that have not been yet investigated. However, some limitations were found during this study. The first concerns the limits in the samples of traditional healers consulted because the majority of people with significant traditional knowledge refuse to provide information through the interviews. Indeed, some participants refuse to give the names of certain plants because they consider that it is a secret in itself and quickly it limits the transmission of this ancestral knowledge. The second limitation concerns the intellectual level of these traditional healers who risk passing information that is not clear enough. The number of traditional healers interviewed is also an important limitation of this study. This limit is indeed due to the low participation of traditional healers in this survey. Moreover, other difficulties related to reaching certain areas of this region because of a bad infrastructure, which justifies the reduced number of questionnaires. In addition, despite the efforts to reach some of these regions, the questionnaire has not been completed because these areas speak the Tamazight language, which we do not speak. In this sense, future work with a well-equipped research team full of linguistic skills could yield other interesting information about traditional knowledge.

\section{Conclusion}

This work has enabled us to inventory forty-six medicinal species used in traditional medicine in the treatment of diabetes, in the Province of Taza. The frequency of the use of medicinal plants is very linked to the profile of the interviewees; younger people generally ignore this know-how. Women and men have shared medicinal knowledge, with a slight difference in favor of the former in terms of the use of medicinal plants. The most widely used medicinal plants in the studied region belong to 28 families, the most popular of which are Lamiaceae, Asteraceae, and Fabaceae. In traditional medicine, the leaves mainly represent the parts of the plant used. The decoction is the galenic form most practiced by the local population whose oral route constitutes the most used route of administration. This study allowed us to appreciate and know the practices of traditional medicine in the treatment of diabetes, transmitted by the population in this region.

\section{Data Availability}

The data used to support the findings of this study are included within the article.

\section{Additional Points}

Highlights. Medicinal plants used by traditional healers to treat diabetes in the Taza region of Morocco were reported. Lamiaceae, Asteraceae, and Fabaceae were the most represented familiesSalvia officinalis L., Marrubium vulgare, and Ajuga iva are the most frequently used medicinal plants against diabetes.

\section{Conflicts of Interest}

The authors declare that they have no conflicts of interest. 


\section{Authors' Contributions}

Hanae Naceiri Mrabti and Latifa Doudach contributed equally in the supervision of this work.

\section{References}

[1] M. Eddouks, A. Lemhadri, and J.-B. Michel, "Hypolipidemic activity of aqueous extract of Capparis spinosa L. in normal and diabetic rats," Journal of Ethnopharmacology, vol. 98, no. 3, pp. 345-350, 2005.

[2] W. Kooti, M. Farokhipour, Z. Asadzadeh et al., "The role of medicinal plants in the treatment of diabetes: a systematic review," Electronic Physician, vol. 8, no. 1, pp. 1832-1842, 2016.

[3] A. Annapurna, M. Kanaka, and K. Murali, "Antidiabetic activity of a polyherbal preparation (tincture of punchparna) in normal and diabetic rats," Indian Journal of Experimental Biology, vol. 39, pp. 500-502, 2001.

[4] A. G. Atanasov, B. Waltenberger, E.-M. Pferschy-wenzig et al., "Discovery and resupply of pharmacologically active plantderived natural products: a review," Biotechnology Advances, vol. 33, no. 8, pp. 1582-1614, 2015.

[5] P. Si Yuan, S. F. Zhou, S. H. Gao et al., "New perspectives on how to discover drugs from herbal medicines: CAM'S outstanding contribution to modern therapeutics," EvidenceBased Complementary and Alternative Medicine, vol. 2013, Article ID 627375, 25 pages, 2013.

[6] E. Idm'hand, F. Msanda, and K. Cherifi, "Ethnopharmacological review of medicinal plants used to manage diabetes in Morocco," Clinical Phytoscience, vol. 6, pp. 1-32, 2020.

[7] H. Jouad, M. Haloui, H. Rhiouani, J. El Hilaly, and M. Eddouks, "Ethnobotanical survey of medicinal plants used for the treatment of diabetes, cardiac and renal diseases in the North centre region of Morocco (Fez-Boulemane)," Journal of Ethnopharmacology, vol. 77, no. 2-3, pp. 175-182, 2001.

[8] M. Barkaoui, A. Katiri, H. Boubaker, and F. Msanda, "Ethnobotanical survey of medicinal plants used in the traditional treatment of diabetes in Chtouka Ait Baha and Tiznit (Western Anti-Atlas), Morocco," Journal of Ethnopharmacology, vol. 198, pp. 338-350, 2017.

[9] H. Ouhaddou, H. Boubaker, F. Msanda, and E. Mousadik Abdelhamid, "An ethnobotanical study of medicinal plants of the Agadir Ida Ou Tanane province (Southwest Morocco)," Journal of Applied Biosciences, vol. 84, no. 1, pp. 7707-7722, 2014.

[10] M. El Mousadik, K. Winkley, and M. von Deden, "For someone who's rich, it's not a problem." Insights from Tanzania on diabetes health-seeking and medical pluralism among Dar es Salaam's urban poor," Globalization and Health, vol. 6, no. 1, p. 8, 2010.

[11] H. N. Mrabti, N. Jaradat, M. R. Kachmar et al., "Integrative herbal treatments of diabetes in Beni Mellal region of Morocco," Journal of Integrative Medicine, vol. 17, no. 2, pp. 93-99, 2019.

[12] I. Mhaidi, S. El, M. A. Kbaich et al., "Molecular identification of Leishmania infection in the most relevant sand fly species and in patient skin samples from a cutaneous leishmaniasis focus, in Morocco," PLOS Neglected Tropical Diseases, vol. 12, pp. 1-13, 2018.

[13] J. Bellakhdar, "La pharmacopée marocaine traditionnelle," Médecine arabe ancienne et savoirs populaires, IBIS Press, Vista, CA, USA, 1997.
[14] M. Fennane, M. Ibn Tatt ou, J. Mathez, A. Ouyahya, and J. El Oualidi, Flore Pratique du Maroc - Manuel de détermination des plantes vasculaires, Trav. Inst. Sci. Rabat, Beltsville, MD, USA, 1999.

[15] M. Hmamouchi, Les plantes médicinales et aromatiques marocaines, 2éme edition, 2001.

[16] S. Vijayakumar, J. E. Morvin Yabesh, S. Prabhu, R. Manikandan, and B. Muralidharan, "Quantitative ethnomedicinal study of plants used in the Nelliyampathy hills of Kerala, India," Journal of Ethnopharmacology, vol. 161, pp. $238-254,2015$.

[17] M. F. Kadir, J. R. Karmoker, M. R. Alam, S. R. Jahan, S. Mahbub, and M. M. K. Mia, "Ethnopharmacological survey of medicinal plants used by traditional healers and indigenous people in Chittagong Hill Tracts, Bangladesh, for the treatment of snakebite," Evidence-Based Complementary and Alternative Medicine, vol. 2015, Article ID 871675, 23 pages, 2015.

[18] F. El Azzouzi and L. Zidane, "La flore médicinale traditionnelle de la région de Béni- Mellal (Maroc)," Journal of Applied Biosciences, vol. 91, no. 1, pp. 8493-8502, 2015.

[19] S. Skalli, R. Hassikou, and M. Arahou, "An ethnobotanical survey of medicinal plants used for diabetes treatment in Rabat, Morocco," Heliyon, vol. 5, no. 3, Article ID e01421, 2019.

[20] P. Daisy and F. G. Jeeva Kani, "Evaluation of antidiabetic activity of various extracts of Cassia auriculata Linn. bark on streptozotocin-induced diabetic wistar rats," International Journal of Pharmacy and Pharmaceutical Sciences, vol. 4, pp. 312-318, 2012.

[21] N. Hamza, B. Berke, C. Cheze et al., "Effect of Centaurium erythraea Rafn, Artemisia herba-alba Asso and Trigonella foenum-graecum L. on liver fat accumulation in C57BL/6J mice with high-fat diet-induced type 2 diabetes," Journal of Ethnopharmacology, vol. 171, pp. 4-11, 2015.

[22] J. Virdi, S. Sivakami, S. Shahani, A. C. Suthar, M. M. Banavalikar, and M. K. Biyani, "Antihyperglycemic effects of three extracts from Momordica charantia," Journal of Ethnopharmacology, vol. 88, no. 1, pp. 107-111, 2003.

[23] G. Yaseen, M. Ahmad, M. Zafar et al., "Traditional management of diabetes in Pakistan: ethnobotanical investigation from traditional health Practitioners," Journal of Ethnopharmacology, vol. 174, pp. 91-117, 2015.

[24] A. Boudjelal, C. Henchiri, L. Siracusa, M. Sari, and G. Ruberto, "Compositional analysis and in vivo anti-diabetic activity of wild Algerian Marrubium vulgare L. infusion," Fitoterapia, vol. 83, no. 2, pp. 286-292, 2012.

[25] M. Bahmani, A. Zargaran, M. Rafieian-Kopaei, and K. Saki, "Ethnobotanical study of medicinal plants used in the management of diabetes mellitus in the Urmia, Northwest Iran," Asian Pacific Journal of Tropical Medicine, vol. 7, pp. S348-S354, 2014.

[26] A. Eidi, M. Eidi, and M. Sokhteh, "Effect of fenugreek (Trigonella foenum-graecum L) seeds on serum parameters in normal and streptozotocin-induced diabetic rats," Nutrition Research, vol. 27, no. 11, pp. 728-733, 2007.

[27] M. A.. Hajzadeh, Z. Rajaei, G. Ghamami, and A. Tamiz, "The effect of Salvia officinalis leaf extract on blood glucose in streptozotocin-diabetic rats," Pharmacologyonline, vol. 1, pp. 213-220, 2011.

[28] A. S. Mohammed and A. T. Berhanu, "Ethnobotanical survey of traditional medicinal plants in Tehuledere district, South Wollo, Ethiopia," Journal of Medicinal Plants Research, vol. 5, pp. 6233-6242, 2011. 
[29] C. Gaube, F. Ziegler, P. Romualdo et al., "Antidiabetic e ff ects of Olea europaea L . leaves in diabetic rats induced by high-fat diet and low-dose streptozotocin," Journal of Ethnopharmacology, vol. 235, pp. 1-7, 2019.

[30] P. K. Prabhakar and M. Doble, "Mechanism of action of natural products used in the treatment of diabetes mellitus," Chinese Journal of Integrative Medicine, vol. 17, no. 8, pp. 563-574, 2011.

[31] Z. Shirdel, H. Madani, and R. Mirbadalzadeh, "Investigation into the hypoglycemic effect of hydroalcoholic extract of Ziziphus Jujuba leaves on blood glucose and lipids in AlloxanInduced diabetes in rats, Iran," Journal of Diabetes and Lipid Disorders, vol. 8, pp. 13-19, 2009.

[32] M. Sharma, "Hypoglycemic and hypolipidimic activity of alcoholic extract of citrus aurantium in normal," Pharmacologyonline, vol. 3, pp. 161-171, 2008.

[33] H. Marrif, B. Ali, and K. M. Hassan, "Some pharmacological studies on Artemisia herba-alba (Asso) in rabbits and mice," Journal of Ethnopharmacology, vol. 8741, 1995.

[34] K. Mansi, M. Amneh, and H. Nasr, "The hypolipidemic effects of Artemisia sieberi (A. herba-alba) in alloxan induced diabetic rats," International Journal of Pharmacology, vol. 3, no. 6, pp. 487-491, 2007.

[35] F. Saad, H. N. Mrabti, K. Sayah et al., "South African Journal of Botany Phenolic content, acute toxicity of Ajuga iva extracts and assessment of their antioxidant and carbohydrate digestive enzyme inhibitory effects," South African Journal of Botany, vol. 125, pp. 381-385, 2019.

[36] S. Ignacimuthu and T. Malraj, "Effect of leaf extract of Zizyphus jujuba on diabetic rats," Indian Journal of Pharmacology, vol. 30, pp. 107-108, 1998.

[37] S. Tiwari, "Plants: a rich source of herbal medicine," Journal of Natural Products, vol. 1, pp. 27-35, 2008.

[38] A. Disha, R. Anita, and S. Anupam, "A review on phytochemistry and ethnopharmacological aspects of genus Calendula," Pharmacognosy Reviews, vol. 7, pp. 179-187, 2013.

[39] M. Song, S. Lee, and D. Kim, "Antidiabetic effect of Chenopodium ambrosioides," Phytopharmacology, vol. 1, pp. 12-15, 2011.

[40] I. Teixidor-toneu, G. J. Martin, A. Ouhammou, R. K. Puri, J. A. Hawkins, and J. A. Hawkins, "An ethnomedicinal survey of a Tashelhit-speaking community in the High Atlas, Morocco," Journal of Ethnopharmacology, vol. 188, pp. 96-110, 2016.

[41] A. Ziyyat, A. Legssyer, H. Mekhfi, A. Dassouli, M. Serhrouchni, and W. Benjelloun, "Phytotherapy of hypertension and diabetes in oriental Morocco," Journal of Ethnopharmacology, vol. 58, no. 1, pp. 45-54, 1997.

[42] M. Eddouks, M. Ajebli, and M. Hebi, "Ethnopharmacological survey of medicinal plants used in Daraa-Tafilalet region (Province of Errachidia), Morocco," Journal of Ethnopharmacology, vol. 198, pp. 516-530, 2017.

[43] M. Hachi, T. Hachi, N. Belahbib, J. Dahmani, and L. Zidane, "Contribution a l'étude floristique et ethnobotanique de la flore médicinale utilisée au niveau de la ville de Khénifra (Maroc)," International Journal of Innovation and Applied Studies, vol. 11, pp. 754-770, 2015.

[44] A. Tahraoui, J. El-Hilaly, Z. H. Israili, and B. Lyoussi, "Ethnopharmacological survey of plants used in the traditional treatment of hypertension and diabetes in south-eastern Morocco (Errachidia province)," Journal of Ethnopharmacology, vol. 110, no. 1, pp. 105-117, 2007.

[45] M. Eddouks, M. Maghrani, A. Lemhadri, M.-L. Ouahidi, and H. Jouad, "Ethnopharmacological survey of medicinal plants used for the treatment of diabetes mellitus, hypertension and cardiac diseases in the south-east region of Morocco (Tafilalet)," Journal of Ethnopharmacology, vol. 82, no. 2-3, pp. 97-103, 2002.

[46] J. El-hilaly, M. Hmammouchi, and B. Lyoussi, "Ethnobotanical studies and economic evaluation of medicinal plants in Taounate province (Northern Morocco)," Journal of Ethnopharmacology, vol. 86, no. 2-3, pp. 149-158, 2003.

[47] M. Ghourri, L. Zidane, and D. Allal, "Usage des s plantes médicinales dans le traitement du Diabète Au Sahara marocain (Tan-Tan)," Journal of Animal and Plant Sciences, vol. 17, 2013.

[48] J. Bellakhdar, R. Claisse, J. Fleurentin, and C. Younos, "Repertory of standard herbal drugs in the Moroccan pharmacopoea," Journal of Ethnopharmacology, vol. 35, no. 2, pp. 123-143, 1991.

[49] H. Orch, A. Douira, and L. Zidane, "Étude ethnobotanique des plantes médicinales utilisées dans le traitement du diabète, et des maladies cardiaques dans la région d'Izarène (Nord du Maroc)," Journal of Applied Biosciences, vol. 86, no. 1, pp. 7940-7956, 2015.

[50] M. Hachi, B. Ouafae, T. Hachi, E. B. Mohamed, and B. Imane, "Contribution to the ethnobotanical study of antidiabetic medicinal plants of the central middle Atlas region (Morocco)," Lazaroa, vol. 37, pp. 135-144, 2016.

[51] A. Bouyahya, J. Abrini, A. Et-touys, Y. Bakri, and N. Dakka, "Indigenous knowledge of the use of medicinal plants in the North-West of Morocco and their biological activities," European Journal of Integrative Medicine, vol. 13, pp. 9-25, 2017.

[52] N. Benlamdini, M. Elhafian, A. Rochdi, and L. Zidane, "Étude floristique et ethnobotanique de la flore médicinale du Haut Atlas oriental (Haute Moulouya)," Journal of Applied Biosciences, vol. 78, pp. 6771-6787, 2014.

[53] J. Fakchich and M. Elachouri, "Ethnobotanical survey of medicinal plants used by people in Oriental Morocco to manage various ailments," Journal of Ethnopharmacology, vol. 154, pp. 76-87, 2014.

[54] O. A. Najla, A. K. Olfat, S. R. Kholoud, N. D. Enas, and I. S. A. Hanan, "Hypoglycemic and biochemical effects of Matricaria chamomilla leave extract in streptozotocin-induced diabetic rats," Journal of Health Science, vol. 2, 2013.

[55] M. Bnouham, H. Mekhfi, and A. Legssyer, "Ethnopharmacology Forum Medicinal plants used in the treatment of diabetes in Morocco," International Journal of Diabetes and Metabolism, vol. 10, pp. 33-50, 2002.

[56] M. A. Mir, S. S. Sawhney, and M. M. S. Jassal, "In-vitro antidiabetic studies of various extracts of Taraxacum officinale," Journal of Pharmaceutical Innovation, vol. 4, pp. 61-66, 2015.

[57] S. Tudies, F. E. Wirngo, M. N. Lambert, and P. B. Jeppesen, "The physiological effects of dandelion (Taraxacum officinale) in type 2 diabetes," Review of Diabeticis Sudies.vol. 13, pp. 113-131, 2016.

[58] N. Chaachouay, O. Benkhnigue, M. Fadli, H. El Ibaoui, and L. Zidane, "Ethnobotanical and ethnopharmacological studies of medicinal and aromatic plants used in the treatment of metabolic diseases in the Moroccan Rif," Heliyon, vol. 5, no. 10, Article ID e02191, 2019.

[59] M. Bnouham, H. Mekhfi, A. Legssyer, and A. Ziyyat, "Medicinal plants used in the treatment of diabetes in Morocco," International Journal of Diabetes and Metabolism, vol. 10, pp. 33-50, 2002, http://ijod.uaeu.ac.ae/iss_1001/e.pdf.

[60] A. Telli, M.-A. Esnault, and A. Ould El Hadj Khelil, "An ethnopharmacological survey of plants used in traditional diabetes treatment in south-eastern Algeria (Ouargla 
province)," Journal of Arid Environments, vol. 127, pp. 82-92, 2016.

[61] M. Kazemian, M. Abad, M. Haeri, and M. Ebrahimi, "Antidiabetic effect of Capparis spinosa L. root extract in diabetic rats," Avicenna Journal of Phytomedicine, vol. 5, pp. 325-332, 2015.

[62] M. Bnouham, F. Z. Merhfour, A. Ziyyat, M. Aziz, A. Legssyer, and H. Mekhfi, "Antidiabetic effect of some medicinal plants of Oriental Morocco in neonatal non-insulin-dependent diabetes mellitus rats," Human \& Experimental Toxicology, vol. 29 , no. 10 , pp. $865-871,2010$.

[63] H. N. Mrabti, K. Sayah, N. Jaradat et al., "Antidiabetic and protective effects of the aqueous extract of Arbutus unedo L. in streptozotocin-nicotinamide-induced diabetic mice," Journal of Complementary and Integrative Medicine, vol. 15, no. 3, pp. 1-11, 2018.

[64] M. El Haouari, S. El Makaoui, M. Jnah, and A. Haddaouy, "A survey of medicinal plants used by herbalists in Taza (Northern Morocco) to manage various ailments," Journal of Materials and Environmental Science, vol. 9, pp. 1875-1888, 2018.

[65] J. El-hilaly, A. Tahraoui, Z. H. Israili, and B. Lyoussi, "Hypolipidemic effects of acute and sub-chronic administration of an aqueous extract of Ajuga iva L. whole plant in normal and diabetic rats," Journal of Ethnopharmacology, vol. 105, no. 3, pp. 441-448, 2006.

[66] M. Eddouks, M. Hebi, M. Ajebli, A. El Hidani, T. Sulpice, and R. Burcelin, "Study of antidiabetic effect of Capparis spinosa L. and Calamintha officinalis Moench in diabetic mice," Phytothérapie.vol. 16, pp. 211-219, 2017.

[67] A. Maghrani, N. A. Zeggwagh, M. Maghrani, H. Jouad, J. B. Michel, and A. Eddouks, "Hypoglycaemic effect of Calamintha officinalis Moench. in normal and streptozotocininduced diabetic rats," Journal of Pharmacy and Pharmacology, vol. 56, pp. 795-799, 2004.

[68] M. Eddouks, A. Lemhadri, and J.-B. Michel, "Caraway and caper: potential anti-hyperglycaemic plants in diabetic rats," Journal of Ethnopharmacology, vol. 94, no. 1, pp. 143-148, 2004.

[69] H. Jouad, M. Maghrani, and M. Eddouks, "Hypoglycemic effect of aqueous extract of Ammi visnaga in normal and streptozotocin-induced diabetic rats," Journal of Herbal Pharmacotherapy, vol. 2, no. 4, pp. 19-29, 2002.

[70] M. Eddouks, M. Maghrani, N.-A. Zeggwagh, and J. B. Michel, "Study of the hypoglycaemic activity of Lepidium sativum L. aqueous extract in normal and diabetic rats," Journal of Ethnopharmacology, vol. 97, no. 2, pp. 391-395, 2005.

[71] M. Eddouks and M. Maghrani, "Effect of Lepidium sativum L. on renal glucose reabsorption and urinary TGF- $\beta 1$ levels in diabetic rats," Phytotherapy Research, vol. 22, no. 1, pp. 1-5, 2008.

[72] F. Gaamoussi, Z. H. Israili, and B. Lyoussi, "Hypoglycemic and hypolipidemic effects of an aqueous extract of Chamaerops humilis leaves in obese, hyperglycemic and hyperlipidemic meriones shawi rats," Pakistan Journal of Pharmaceutical Sciences, vol. 23, no. 2, pp. 212-219, 2010.

[73] M. Eddouks, A. Lemhadri, M. Hebi et al., "Capparis spinosa L. aqueous extract evokes antidiabetic effect in streptozotocininduced diabetic mice," Avicenna Journal of Phytomedicine, vol. 7, pp. 191-198, 2017.

[74] H. Jouad, A. Lemhadri, M. Maghrani, R. Burcelin, and M. Eddouks, "Hawthorn evokes a potent anti-hyperglycemic capacity in streptozotocin-induced diabetic rats," Journal of Herbal Pharmacotherapy, vol. 3, no. 2, pp. 19-29, 2003.
[75] B. Meddah, R. Ducroc, M. El Abbes Faouzi et al., "Nigella sativa inhibits intestinal glucose absorption and improves glucose tolerance in rats," Journal of Ethnopharmacology, vol. 121, no. 3, pp. 419-424, 2009.

[76] P. Mai, A. Benhaddou-andaloussi, A. Elimadi, A. Settaf, Y. Cherrah, and P. S. Haddad, "The petroleum ether extract of Nigella sativa exerts lipid-lowering and insulin-sensitizing actions in the rat," Journal of Ethnopharmacology, vol. 94, pp. 251-259, 2004.

[77] A. Benhaddou-andaloussi, L. Martineau, T. Vuong et al., "The in vivo antidiabetic activity of Nigella sativa is mediated through activation of the AMPK pathway and increased muscle Glut4 content," Evidence-Based Complementary and Alternative Medicine, vol. 2011, Article ID 538671, 9 pages, 2011.

[78] A.-M. Abudunia, I. Marmouzi, M. Kharbach et al., "Hypoglycemic effect of Calendula arvensis flowers is mediated by digestive enzyme inhibition," Current Bioactive Compounds, vol. 16, no. 5, pp. 588-592, 2020.

[79] I. Marmouzi, M. Kharbach, M. El Jemli et al., “Antidiabetic, dermatoprotective, antioxidant and chemical functionalities in Zizyphus lotus leaves and fruits," Industrial Crops and Products, vol. 132, pp. 134-139, 2019.

[80] M. Bnouham, F.-Z. Merhfour, A. Ziyyat, H. Mekhfi, M. Aziz, and A. Legssyer, "Antihyperglycemic activity of the aqueous extract of Urtica dioica," Fitoterapia, vol. 74, no. 7-8, pp. 677-681, 2003.

[81] M. S. Kpodar, P. Lawson-evi, B. Bakoma et al., "Ethnopharmacological survey of plants used in the treatment of diabetes mellitus in south of Togo (Maritime Region)," Journal of Herbal Medicine, vol. 5, no. 3, pp. 147-152, 2015.

[82] A. Begossi, N. Hanazaki, and J. Y. Tamashiro, "Medicinal plants in the Atlantic forest (Brazil): knowledge, use, and conservation," Human Ecology, vol. 30, no. 3, pp. 281-299, 2002.

[83] I. O. Ishola, I. A. Oreagba, A. A. Adeneye, C. Adirije, K. A. Oshikoya, and O. O. Ogunleye, "Ethnopharmacological survey of herbal treatment of malaria in Lagos, Southwest Nigeria," Journal of Herbal Medicine, vol. 4, no. 4, pp. 224-234, 2014.

[84] S. A. Sargin, "Ethnobotanical survey of medicinal plants in bozyazi district of mersin, Turkey," Journal of Ethnopharmacology, vol. 173, 2015.

[85] S. D. Karou, T. Tchacondo, M. A. Djikpo Tchibozo et al., "Ethnobotanical study of medicinal plants used in the management of diabetes mellitus and hypertension in the central region of Togo," Pharmaceutical Biology, vol. 49, no. 12, pp. 1286-1297, 2011.

[86] K. Dizaye and K. H. Badr-Aldin, "Cardiovascular studies of white squill (Urginea maritima) extract," Zanco Journal of Medical Sciences, vol. 14, 2010.

[87] N. U. Islam, K. Jalil, M. Shahid et al., "Green synthesis and biological activities of gold nanoparticles functionalized with Salix alba," Arabian Journal of Chemistry, vol. 12, no. 8, pp. 2914-2925, 2019.

[88] L. K. Keter and P. C. Mutiso, "Ethnobotanical studies of medicinal plants used by traditional health practitioners in the management of diabetes in lower eastern province, Kenya," Journal of Ethnopharmacology, vol. 139, no. 1, pp. 74-80, 2012.

[89] L. Fah, J. Klotoé, V. Dougnon, H. Koudokpon, and V. Fanou, "Étude ethnobotanique des plantes utilisées dans le traitement $\mathrm{du}$ diabète chez les femmes enceintes à Cotonou et AbomeyCalavi ( Bénin )," Journal of Animal and Plant Sciences, vol. 18, pp. 2647-2658, 2013. 
[90] M. Ullah, M. U. Khan, A. Mahmood et al., "An ethnobotanical survey of indigenous medicinal plants in Wana district south Waziristan agency, Pakistan," Journal of Ethnopharmacology, vol. 150, no. 3, pp. 918-924, 2013.

[91] B. Benarba, L. Belabid, K. Righi et al., "Ethnobotanical study of medicinal plants used by traditional healers in Mascara (North West of Algeria)," Journal of Ethnopharmacology, vol. 175, pp. 626-637, 2015.

[92] H. Mrabti, N. Jaradat, I. Fichtali et al., "Separation, identification, and antidiabetic activity of catechin isolated from Arbutus unedo L. Plant roots," Plants, vol. 7, no. 2, pp. 31-39, 2018. 